\title{
Studies on Influence of Nitrogen and Weed Management on Growth Characters of Late Sown Wheat (Triticum aestivum L.)
}

\author{
Ankit Tiwari", O. P. Rai, Ghanshyam Singh, Manoj Kumar, Deepak Pandey and Harikesh \\ Department of Agronomy, N. D. University of Agriculture and Technology, \\ Kumarganj, Faizabad-224 229, India \\ *Corresponding author
}

A B S T R A C T

A field experiment was conducted during rabi season of 2014-15 and 2015-16 with an objective to find out the effect of weed control treatments on crop \& associated weeds and to determine a competitive understanding of the effect of various nitrogen management

Keywords

FYM, Nitrogen management, Weed management, Late sown wheat, Growth parameters.

\section{Article Info}

Accepted:

17 September 2017 Available Online:

10 November 2017 practices on productivity of wheat crop. The experiment was laid out in Split plot design with 16 treatment combinations viz. $\mathrm{F}_{1}: \mathrm{RDN}\left(120 \mathrm{Kgha}^{-1}\right), \mathrm{F}_{2}: 25 \% \mathrm{~N} \mathrm{FYM+75 \%} \mathrm{N}$ through chemical fertilizer, $\mathrm{F}_{3}: 50 \% \mathrm{~N} \mathrm{FYM}+50 \% \mathrm{~N}$ through chemical fertilizer, $\mathrm{F}_{4}: 75 \% \mathrm{~N}$ $\mathrm{FYM}+25 \% \mathrm{~N}$ through chemical fertilizer under nitrogen management practices in main plot and $\mathrm{W}_{0}$ :Weedy check, $\mathrm{W}_{1}$ :Weed free, $\mathrm{W}_{2}$ :VESTA (Clodinafop $15 \%+$ metsulfuron methyl 1\%), $\mathrm{W}_{3}$ :TOTAL (Sulfosulfuron 75\% + metsulfuron methyl 5\%) under weed management treatments in sub plot with three replications. Nitrogen management practices affects significantly with treatment $\mathrm{F}_{1}: \operatorname{RDN}\left(120 \mathrm{kgha}^{-1}\right)$ being at par with $\mathrm{F}_{2}: 25 \% \mathrm{~N} \mathrm{FYM}$ $+75 \% \mathrm{~N}$ through chemical fertilizer increases the plant height, number of shoots, dry matter accumulation and leaf area index. Application of VESTA (Clodinafop 15\% + metsulfuron methyl 1\%) $\left(\mathrm{W}_{2}\right)$ being at par with TOTAL (Sulfosulfuron $75 \%+$ metsulfuron methyl 5\%) $\left(\mathrm{W}_{3}\right)$ found significantly superior over weedy check and produced taller plants $(102.45$ and $104.15 \mathrm{~cm})$, maximum number of shoots $(354.78$ and 374.94), dry matter accumulation (890.83 and 920.83) and leaf area index (4.32 and 4.45) as compared to the weedy check.

\section{Introduction}

Wheat (Triticum aestivum L.) is the second most important winter cereal in India after rice, contributing substantially to the national food security by providing more than $50 \%$ of the calories to the people who mainly depend on it. Wheat (Triticum aestivum L.) is the most important cereal food crop for more than half of the world's population. Asia, with 60 per cent of the global population, accounts for about 92 per cent of the world's wheat production and 90 per cent of global wheat consumption. Wheat is a staple food of the world and comes under Poaceae family. It is rabi season crop primarily grown in temperate regions and also at higher altitude under tropical climatic areas in winter season. It is the single most important cereal crop that has been considered as integral component of the food security system of the several nations. It ranks first in the world among the cereals both in respect of area (225.07 m ha) and production (736.98 $\mathrm{m}$ tonnes). In India, total area under wheat is $31.72 \mathrm{~m}$ ha with the production and productivity of $96.0 \mathrm{~m}$ tonnes 
and 3.13 tonnes $\mathrm{ha}^{-1}$, respectively (USDA, 2017).

Major wheat producing countries in the world are China, India, USA, France, Russia, Canada, Australia, Pakistan, Turkey, UK, Argentina, Iran and Italy. These countries contribute about $74.82 \%$ of the total world wheat production. As far as India is concerned, about $90 \%$ of the total wheat production is contributed by northern states. Among them, Uttar Pradesh ranks first with respect to area $(9.75 \mathrm{~m} \mathrm{ha})$ and production (30.30 $\mathrm{m}$ tonnes) but the productivity is much lower (3113 $\left.\mathrm{kgha}^{-1}\right)$ than Punjab $(5097 \mathrm{~kg}$ $\mathrm{ha}^{-1}$ ) and Haryana (5182 $\mathrm{kgha}^{-1}$ ) (Anonymous, 2015). However, modern chemical based agriculture practices have led to several new challenges, viz., declining productivity, degradation of soil and water resources, diminishing biodiversity and increase in environmental pollution. Under such situation organic nutrient management has significant role in improving productivity of crop and soil fertility. Continuous use of chemical fertilizer has increased the crop yield, but caused many environmental problems including soil, air and water pollution and finally human health hazard and making the crop productivity unsustainable (Eid et al., 2006). Application of organo-inorganic combination is very effective in realization of high yield and high responses to added nutrients. Incorporation of farm waste as biological as well as practice of green manuring in cereals is viable options, which improves the productivity and partially substitutes the fertilizer nitrogen requirement of the subsequent crop. Organic manures provide regulate supply of $\mathrm{N}$ by releasing it slowly resulting in increased yield of crop and nutrient use efficiency (Sharma 2002). Keeping all above facts in view the present study was undertaken to find out the effect of weed control treatments on crop \& associated weeds and to determine a competitive understanding of the effect of various nitrogen management practices on productivity of wheat crop.

\section{Materials and Methods}

The present investigation entitled "Effect of nitrogen and weed management on performance of late sown wheat" was under taken during rabi 2014-15 and 2015-16 initiated at the Agronomy Research Farm of Narendra Deva University of Agriculture and Technology, Kumarganj, Faizabad. The experiment was conducted which is situated on Faizabad- Raibarely road about $42 \mathrm{~km}$ away from Faizabad. The experimental site falls under subtropical climate in IndoGangetic plains having alluvial calcareous soil and lies between $26^{\circ} 47^{\prime}$ North latitude and $82^{\circ} 12^{\prime}$ East longitude at an altitude of $113 \mathrm{~m}$ from mean sea level. The region receives annual rainfall ranging from 1000$1200 \mathrm{~mm}$ and 90 per cent of which is received in Mid-June to end of September. The soil of the experimental field was silt loam, having of pH $8.15 \& 8.21$, organic carbon (\%) 0.38 \& 0.40 , available N, P and K $115.47 \& 126.46$ $\mathrm{kgha}^{-1}, 15.60 \& 17.22 \mathrm{kgha}^{-1}$ and $245.46 \&$ $250.47 \mathrm{kgha}^{-1}$ respectively. The sowing was done on $26^{\text {th }}$ Dec. 2014 and $20^{\text {th }}$ Dec. 2015 using wheat cultivar HUW-234 at the spacing of $20 \times 20 \mathrm{~cm}$. There are 4 main plot and $4 \mathrm{sub}$ plot as detailed below:

Main plots are $\mathrm{F}_{1}$ : RDN $\left(120 \mathrm{Kgha}^{-1}\right), \mathrm{F}_{2}: 25 \%$ $\mathrm{N}$ FYM+75\% $\mathrm{N}$ through chemical fertilizer, $\mathrm{F}_{3}: 50 \% \mathrm{~N}$ FYM+50\% $\mathrm{N}$ through chemical fertilizer, $\mathrm{F}_{4}: 75 \% \mathrm{~N}$ FYM+25\% $\mathrm{N}$ through chemical fertilizer and in sub plots are $\mathrm{W}_{0}$ :Weedy check, $\mathrm{W}_{1}$ :Weed free, $\mathrm{W}_{2}$ :VESTA (Clodinafop 15\% + metsulfuron methyl 1\%), $\mathrm{W}_{3}$ :TOTAL (Sulfosulfuron $75 \%+$ metsulfuron methy 1 5\%) Note:Recommended dose of fertilizer (100\%); 120 $\mathrm{kg} \mathrm{N}, 60 \mathrm{~kg} \mathrm{P}_{2} \mathrm{O}_{5}$ and $60 \mathrm{~kg} \mathrm{~K}_{2} \mathrm{O} \mathrm{ha}^{-1}$ for wheat crop. 
Observations were recorded at different growth stages of wheat crop. The plant height of five tagged plants selected randomly from each plot was recorded with the help of meter scale at 30, 60, 90 DAS and at harvest. The no. of shoots was counted at 30, 60, 90 DAS and at harvest, from 4 places of $0.25 \mathrm{~m}^{2}$ selected randomly in each net plot. The average values were taken. Plants of the quadrate of $0.25 \mathrm{~m}^{2}$ from the border of both the side from four places selected randomly at 30, 60, 90 DAS and at harvest were cut close to the ground surface, the sun dried and were put in paper bags for oven drying at $65^{\circ}-70^{\circ}$ $\mathrm{C}$ till the constant weight. The leaf area for one leaf from each group was computed with the help of formula given by Yoshida et al., (1972) and multiplied with the total leaves from each group. LAI (leaf area index) was calculated from the data on the leaf area according to the formula given by Watson (1947).

\section{Results and Discussion}

The data on growth parameters viz., initial plant population, plant height, no. of shoots, dry matter accumulation and leaf area index (LAI) increased significantly with treatment $100 \%$ RDF $\left(\mathrm{F}_{1}\right)$ and being at par with $25 \%$ $\mathrm{N}-\mathrm{FYM}+75 \% \mathrm{~N}$ through chemical fertilizer $\left(\mathrm{F}_{2}\right)$ except initial plant population at 20 DAS was found non-significant (Table 1). The maximum plant height was found with $100 \%$ RDF treatment $\left(\mathrm{F}_{1}\right)$ being at par with $25 \% \mathrm{~N}-\mathrm{FYM}+75 \% \mathrm{~N}$ through chemical fertilizer $\left(\mathrm{F}_{2}\right)$ and significantly superior over rest of the treatments at all the growth stages during the course of investigation except at 30 DAS which was found non-significant under nitrogen management practices (Table 2). This might be due to full nitrogen dose through chemical source results higher nitrogen uptake, which ultimately results into increased protein synthesis, cell division and cell elongation and enlargement which expressed morphologically an increase in height of plant. Similar findings were reported by Chandra Shekhar et al., (1992). Treatment $\left(\mathrm{W}_{2}\right)$ VESTA (Clodinafop 15\% + MSM 1\%) produced significantly taller plants and being at par with $\left(\mathrm{W}_{3}\right)$ TOTAL (Sulfosulfuron $75 \%$ + MSM 5\%) over rest of the treatments at all growth stages. VESTA $400 \mathrm{~g} \mathrm{ha}^{-1}$ (Clodinafop $15 \%+$ metsulfuron methyl 1\%) treatment achieved highest height might be because of the fact that both type of weeds e.g., broad leaf and narrow leaved controlled to a reasonable extent, resulting very less competition of various weed species with crop plants and ultimately found more plant height and likewise low plant height was recorded in weedy check because of maximum weed population in weedy check which reduced the plant height. The same trend was also found in numbers of shoots $\left(\mathrm{m}^{-2}\right)$ (Table 3).

The maximum number of shoots $\left(\mathrm{m}^{-2}\right)$ was recorded with $\mathrm{F}_{1}(100 \% \mathrm{RDF})$ (354.78 and 374.94) which was significantly superior over other treatments and being at par with $\mathrm{F}_{2}(25 \% \mathrm{~N}-\mathrm{FYM}+75 \% \mathrm{~N}$ through chemical fertilizer) under nitrogen management practices. It might be due to the fast rate mineralization of chemical source of nitrogen which was sufficient for plant growth and development. Similar results were reported by Upadhyay and Tiwari (1996). The minimum number of shoots $\left(\mathrm{m}^{-2}\right)$ was found with $\mathrm{F}_{4}$ $(75 \% \mathrm{~N}-\mathrm{FYM}+25 \% \mathrm{~N}$ through chemical fertilizer) (304.59 and 323.05). Under weed management treatments, maximum number of shoots were recorded with VESTA $400 \mathrm{~g} \mathrm{ha}^{-1}$ (354.78 and $374.94 \mathrm{~m}^{-2}$ ) $\mathrm{fb}$ Total $32 \mathrm{~g} \mathrm{ha}^{-1}$ (337.19 and $360.64 \mathrm{~m}^{-2}$ ), though differences were at par. Clodinafop control narrow leaved weeds and metsulfuron methyl control the broad leaved and narrow leaved weeds efficiently, so this factor may be responsible due to which highest number of shoots were achieved during both the years of investigation. 
Table.1 Effect of nitrogen and weed management on initial plant population in wheat crop

\begin{tabular}{|l|c|c|}
\hline \multirow{2}{*}{ Treatments } & $\begin{array}{c}\text { Initial Plant Population } \\
\text { (20 DAS) (per running meter) }\end{array}$ \\
\cline { 2 - 3 } & $\mathbf{2 0 1 4 - 1 5}$ & $\mathbf{2 0 1 5 - 1 6}$ \\
\hline Nitrogen management (Main plot) & 34.40 & 35.10 \\
\hline RDN (120 $\mathrm{kgha}^{-1}$ ) & 36.11 & 36.85 \\
\hline 25\% N through FYM + 75\% N chemical fertilizer & 37.78 & 38.55 \\
\hline 50\% N through FYM + 50\% N chemical fertilizer & 37.34 & 38.10 \\
\hline $75 \%$ N through FYM + 25\% N chemical fertilizer & 0.661 & 0.881 \\
\hline SEm \pm & $\mathrm{NS}$ & $\mathrm{NS}$ \\
\hline CD at 5\% & \multicolumn{2}{|l}{} \\
\hline Weed management (Sub plot) & 35.18 & 35.90 \\
\hline Weedy check & 36.70 & 37.45 \\
\hline Weed free & 36.06 & 36.80 \\
\hline VESTA (Clodinafop 15\% + MSM 1\%) & 37.68 & 38.45 \\
\hline Total (Sulfosulfuron 75\% + MSM 5\%) & 0.84 & 0.82 \\
\hline SEm \pm & $\mathrm{NS}$ & $\mathrm{NS}$ \\
\hline CD at 5\% & \multicolumn{2}{|l}{} \\
\hline
\end{tabular}

Table.2 Effect of nitrogen and weed management on plant height of wheat crop

\begin{tabular}{|c|c|c|c|c|c|c|c|c|}
\hline \multirow{3}{*}{ Treatments } & \multicolumn{8}{|c|}{ Plant height (cm) } \\
\hline & \multicolumn{2}{|c|}{30 DAS } & \multicolumn{2}{|c|}{60 DAS } & \multicolumn{2}{|c|}{90 DAS } & \multicolumn{2}{|c|}{120 DAS } \\
\hline & 2014-15 & 2015-16 & 2014-15 & 2015-16 & 2014-15 & 2015-16 & 2014-15 & 2015-16 \\
\hline \multicolumn{9}{|c|}{ Nitrogen management (Main plot) } \\
\hline $\mathbf{F}_{1}$ & 19.90 & 20.10 & 61.01 & 64.06 & 80.25 & 82.66 & 101.24 & 103.24 \\
\hline $\mathbf{F}_{2}$ & 20.30 & 20.51 & 57.93 & 60.83 & 76.21 & 78.50 & 96.13 & 98.05 \\
\hline $\mathbf{F}_{3}$ & 20.10 & 20.30 & 54.86 & 57.60 & 72.17 & 74.34 & 91.03 & 92.85 \\
\hline $\mathbf{F}_{4}$ & 19.70 & 19.90 & 53.01 & 55.66 & 69.75 & 71.84 & 87.96 & 89.74 \\
\hline SEm \pm & 0.44 & 0.38 & 1.39 & 1.12 & 1.70 & 1.81 & 1.71 & 2.20 \\
\hline CD at $5 \%$ & NS & NS & 5.46 & 4.39 & 6.66 & 7.13 & 6.71 & 8.65 \\
\hline \multicolumn{9}{|c|}{ Weed management (Sub plot) } \\
\hline $\mathbf{W}_{\mathbf{0}}$ & 19.40 & 19.60 & 40.35 & 42.37 & 52.92 & 54.50 & 66.95 & 68.08 \\
\hline $\mathbf{W}_{1}$ & 22.10 & 22.31 & 66.04 & 69.34 & 86.65 & 89.24 & 109.58 & 111.47 \\
\hline $\mathbf{W}_{2}$ & 19.70 & 19.90 & 61.74 & 64.83 & 80.95 & 83.38 & 102.45 & 104.15 \\
\hline $\mathbf{W}_{3}$ & 18.80 & 19.00 & 58.68 & 61.61 & 77.87 & 80.20 & 97.37 & 100.18 \\
\hline SEm \pm & 0.47 & 0.47 & 1.21 & 1.46 & 1.61 & 2.05 & 2.02 & 2.40 \\
\hline CD at $5 \%$ & 1.35 & 1.37 & 3.51 & 4.21 & 4.64 & 5.93 & 5.83 & 6.94 \\
\hline
\end{tabular}

Where,

$\mathrm{F}_{1}: \operatorname{RDN}\left(120 \mathrm{kgha}^{-1}\right)$

$\mathrm{F}_{2} \quad: \quad 25 \% \mathrm{~N}$ through $\mathrm{FYM}+75 \% \mathrm{~N}$ chemical fertilizer

$\mathrm{F}_{3} \quad 50 \% \mathrm{~N}$ through $\mathrm{FYM}+50 \% \mathrm{~N}$ chemical fertilizer

$\mathrm{F}_{4} \quad 75 \% \mathrm{~N}$ through $\mathrm{FYM}+25 \% \mathrm{~N}$ chemical fertilizer
$\mathrm{W}_{0} \quad$ : Weedy check

$\mathrm{W}_{1} \quad$ : Weed free

$\mathrm{W}_{2} \quad$ VESTA (Clodinafop $15 \%+$ MSM $1 \%$ )

$\mathrm{W}_{3} \quad$ : Total (Sulfosulfuron $75 \%+$ MSM 5\%) 
Table.3 Effect of nitrogen and weed management on no. of shoots of wheat crop

\begin{tabular}{|c|c|c|c|c|c|c|c|c|}
\hline \multirow{3}{*}{ Treatments } & \multicolumn{8}{|c|}{ No. of shoots $\left(\mathrm{m}^{-2}\right)$} \\
\hline & \multicolumn{2}{|c|}{30 DAS } & \multicolumn{2}{|c|}{ 60 DAS } & \multicolumn{2}{|c|}{90 DAS } & \multicolumn{2}{|c|}{ 120 DAS } \\
\hline & 2014-15 & 2015-16 & 2014-15 & 2015-16 & 2014-15 & 2015-16 & 2014-15 & $2015-16$ \\
\hline \multicolumn{9}{|c|}{ Nitrogen management (Main plot) } \\
\hline $\mathbf{F}_{1}$ & 163.36 & 164.32 & 328.52 & 338.57 & 368.96 & 391.23 & 350.58 & 371.67 \\
\hline $\mathbf{F}_{2}$ & 159.13 & 160.04 & 311.99 & 321.53 & 350.39 & 371.55 & 332.89 & 352.97 \\
\hline $\mathbf{F}_{3}$ & 157.74 & 158.63 & 295.46 & 304.50 & 331.83 & 351.86 & 315.21 & 334.27 \\
\hline $\mathbf{F}_{4}$ & 158.32 & 159.22 & 285.54 & 294.27 & 320.69 & 340.05 & 304.59 & 323.05 \\
\hline SEm \pm & 2.37 & 2.42 & 5.74 & 7.73 & 6.44 & 8.27 & 7.69 & 6.28 \\
\hline CD at $5 \%$ & NS & NS & 22.53 & 30.33 & 25.30 & 32.46 & 30.18 & 24.66 \\
\hline \multicolumn{9}{|c|}{ Weed management (Sub plot) } \\
\hline$W_{0}$ & 160.00 & 160.90 & 216.62 & 223.25 & 243.29 & 257.97 & 231.85 & 245.08 \\
\hline $\mathbf{W}_{1}$ & 163.24 & 164.18 & 354.71 & 365.55 & 398.37 & 422.42 & 379.46 & 401.30 \\
\hline $\mathbf{W}_{2}$ & 161.97 & 162.89 & 331.41 & 341.55 & 372.20 & 394.68 & 354.78 & 374.94 \\
\hline $\mathbf{W}_{3}$ & 161.33 & 162.24 & 318.77 & 328.52 & 358.01 & 379.62 & 337.19 & 360.64 \\
\hline SEm \pm & 2.40 & 2.48 & 7.47 & 6.75 & 8.39 & 7.83 & 8.69 & 7.40 \\
\hline CD at $5 \%$ & NS & NS & 21.58 & 19.51 & 24.23 & 22.61 & 25.11 & 21.36 \\
\hline \multicolumn{9}{|l|}{ Where, } \\
\hline $\begin{array}{lll}\mathrm{F}_{1}: & \mathrm{RI} \\
\mathrm{F}_{2} & : & 25 \\
\mathrm{~F}_{3} & & 50 \\
\mathrm{~F}_{4} & & 75\end{array}$ & $\begin{array}{l}120 \mathrm{kgha}^{-1} \text { ) } \\
\text { through } \mathrm{F} \\
\text { through } \mathrm{F} \\
\text { through } \mathrm{F}\end{array}$ & $\begin{array}{l}+75 \% \mathrm{Nc} \\
+50 \% \mathrm{Nc} \\
+25 \% \mathrm{Nc}\end{array}$ & $\begin{array}{l}\text { nical fertilize } \\
\text { nical fertilize } \\
\text { nical fertilize }\end{array}$ & $\begin{array}{l}\mathrm{W}_{0} \\
\mathrm{~W}_{1} \\
\mathrm{~W}_{2} \\
\mathrm{~W}_{3}\end{array}$ & $\begin{array}{l}\text { Weedy ch } \\
\text { Weed free } \\
\text { VESTA (C } \\
\text { Total (Sul }\end{array}$ & $\begin{array}{l}\text { inafop } 15 \% \\
\text { lfuron } 75 \%\end{array}$ & $\begin{array}{l}\text { MSM 1\%) } \\
\text { MSM 5\%) }\end{array}$ & \\
\hline
\end{tabular}

Table.4 Effect of nitrogen and weed management on dry matter accumulation of wheat crop

\begin{tabular}{|c|c|c|c|c|c|c|c|c|}
\hline \multirow{3}{*}{ Treatments } & \multicolumn{8}{|c|}{ Dry matter accumulation $\left(\mathrm{g} \mathrm{m}^{-2}\right)$} \\
\hline & \multicolumn{2}{|c|}{30 DAS } & \multicolumn{2}{|c|}{ 60 DAS } & \multicolumn{2}{|c|}{90 DAS } & \multicolumn{2}{|c|}{$120 \mathrm{DAS}$} \\
\hline & 2014-15 & 2015-16 & 2014-15 & 2015-16 & 2014-15 & $2015-16$ & 2014-15 & $2015-16$ \\
\hline \multicolumn{9}{|c|}{ Nitrogen management (Main plot) } \\
\hline $\mathbf{F}_{1}$ & 45.41 & 47.22 & 403.36 & 416.42 & 733.37 & 757.13 & 916.72 & 946.41 \\
\hline $\mathbf{F}_{2}$ & 43.70 & 45.45 & 376.37 & 388.50 & 684.30 & 706.35 & 855.38 & 882.94 \\
\hline $\mathbf{F}_{3}$ & 42.63 & 44.33 & 356.30 & 367.77 & 647.82 & 668.67 & 809.78 & 835.84 \\
\hline $\mathbf{F}_{4}$ & 41.83 & 43.50 & 344.27 & 355.33 & 625.94 & 646.06 & 782.42 & 807.57 \\
\hline SEm \pm & 0.93 & 0.80 & 8.99 & 7.20 & 15.14 & 16.47 & 15.49 & 19.73 \\
\hline CD at $5 \%$ & $\mathrm{NS}$ & NS & 35.29 & 28.26 & 59.46 & 64.67 & 60.83 & 77.47 \\
\hline \multicolumn{9}{|c|}{ Weed management (Sub plot) } \\
\hline $\mathbf{W}_{0}$ & 39.79 & 41.38 & 282.12 & 292.74 & 512.94 & 532.25 & 641.18 & 665.31 \\
\hline $\mathbf{W}_{1}$ & 42.98 & 44.70 & 419.73 & 433.10 & 763.14 & 787.45 & 953.93 & 984.31 \\
\hline $\mathbf{W}_{2}$ & 46.44 & 48.30 & 391.97 & 405.17 & 712.66 & 736.66 & 890.83 & 920.83 \\
\hline $\mathbf{W}_{3}$ & 44.35 & 46.12 & 386.48 & 397.01 & 702.69 & 721.84 & 878.36 & 902.30 \\
\hline SEm \pm & 1.00 & 1.02 & 7.90 & 9.15 & 14.39 & 18.19 & 18.28 & 21.17 \\
\hline CD at $5 \%$ & 2.90 & 2.96 & 22.83 & 26.43 & 41.55 & 52.53 & 52.81 & 61.14 \\
\hline
\end{tabular}

Where,
$\mathrm{F}_{1} \quad: \quad \mathrm{RDN}\left(120 \mathrm{kgha}^{-1}\right)$

$\mathrm{F}_{2} \quad: \quad 25 \% \mathrm{~N}$ through $\mathrm{FYM}+75 \% \mathrm{~N}$ chemical fertilizer

$\mathrm{F}_{3} \quad 50 \% \mathrm{~N}$ through FYM $+50 \% \mathrm{~N}$ chemical fertilizer

$\mathrm{F}_{4} \quad 75 \% \mathrm{~N}$ through $\mathrm{FYM}+25 \% \mathrm{~N}$ chemical fertilizer
$\mathrm{W}_{0} \quad$ : Weedy check

$\mathrm{W}_{1}$ : Weed free

$\mathrm{W}_{2} \quad$ VESTA (Clodinafop 15\% + MSM 1\%)

$\mathrm{W}_{3} \quad$ : Total (Sulfosulfuron $75 \%+$ MSM $5 \%$ ) 
Table.5 Effect of nitrogen and weed management on leaf area index of wheat crop

\begin{tabular}{|c|c|c|c|c|c|c|}
\hline \multirow{3}{*}{ Treatments } & \multicolumn{6}{|c|}{ Leaf area index } \\
\hline & \multicolumn{2}{|c|}{ 30 DAS } & \multicolumn{2}{|c|}{ 60 DAS } & \multicolumn{2}{|c|}{90 DAS } \\
\hline & 2014-15 & 2015-16 & 2014-15 & 2015-16 & 2014-15 & 2015-16 \\
\hline \multicolumn{7}{|c|}{ Nitrogen management (Main plot) } \\
\hline$F_{1}$ & 1.40 & 1.38 & 3.27 & 3.43 & 4.25 & 4.38 \\
\hline $\mathbf{F}_{2}$ & 1.39 & 1.41 & 3.12 & 3.27 & 4.05 & 4.18 \\
\hline $\mathbf{F}_{3}$ & 1.41 & 1.41 & 2.99 & 3.14 & 3.88 & 4.00 \\
\hline $\mathbf{F}_{4}$ & 1.39 & 1.39 & 2.90 & 3.05 & 3.77 & 3.88 \\
\hline SEm \pm & 0.02 & 0.03 & 0.06 & 0.07 & 0.09 & 0.08 \\
\hline CD at $5 \%$ & NS & NS & 0.23 & 0.26 & 0.37 & 0.30 \\
\hline \multicolumn{7}{|c|}{ Weed management (Sub plot) } \\
\hline $\mathbf{W}_{0}$ & 1.38 & 1.39 & 2.28 & 2.39 & 2.96 & 3.05 \\
\hline $\mathbf{W}_{1}$ & 1.40 & 1.41 & 3.42 & 3.59 & 4.45 & 4.58 \\
\hline $\mathbf{W}_{2}$ & 1.41 & 1.38 & 3.33 & 3.49 & 4.32 & 4.45 \\
\hline $\mathbf{W}_{3}$ & 1.40 & 1.41 & 3.25 & 3.41 & 4.23 & 4.35 \\
\hline SEm \pm & 0.03 & 0.03 & 0.07 & 0.08 & 0.11 & 0.09 \\
\hline CD at $5 \%$ & NS & NS & 0.21 & 0.23 & 0.30 & 0.25 \\
\hline
\end{tabular}

Where,

$\mathrm{F}_{1} \quad: \quad \operatorname{RDN}\left(120 \mathrm{kgha}^{-1}\right)$

$\mathrm{F}_{2} \quad: \quad 25 \% \mathrm{~N}$ through $\mathrm{FYM}+75 \% \mathrm{~N}$ chemical fertilizer

$\mathrm{F}_{3} \quad 50 \% \mathrm{~N}$ through $\mathrm{FYM}+50 \% \mathrm{~N}$ chemical fertilizer

$\mathrm{F}_{4} \quad 75 \% \mathrm{~N}$ through FYM $+25 \% \mathrm{~N}$ chemical fertilizer

Dry matter accumulation $\left(\mathrm{gm}^{-1}\right)$ row length recorded at various growth stages is presented in (Table 4). There was also significant increase in dry matter accumulation with $100 \% \mathrm{RDF}$ at all the growth stages and the maximum dry matter accumulation was noticed with $\mathrm{F}_{1}(100 \%$ RDF) (916.72 and $946.41 \mathrm{~g})$ which was significantly superior over rest of the treatments under nitrogen management practices during both the years. Significantly more dry matter accumulation was recorded with $100 \%$ RDF might be attributed due to more synthesis of food material in plants. Similar findings were reported by Singh (1991) and Bhagwati et al., (1992). Maximum dry matter accumulation was found due to VESTA $400 \mathrm{~g} \mathrm{ha}^{-1}\left(890.83\right.$ and $920.75 \mathrm{~g} \mathrm{~m}^{-2}$ ) which is at par with Total $32 \mathrm{~g} \mathrm{ha}^{-1}(878.36$ and $902.30 \mathrm{~g} \mathrm{~m}^{-2}$ ). This might be due to the effective control of BLWs and narrow leaf weeds also. However, clodinafop control the
$\mathrm{W}_{0} \quad$ : Weedy check

$\mathrm{W}_{1}$ : Weed free

$\mathrm{W}_{2} \quad$ VESTA (Clodinafop $15 \%+$ MSM $1 \%$ )

$\mathrm{W}_{3}$ : Total (Sulfosulfuron $75 \%+$ MSM 5\%)

narrow leaved and metsulfuron methyl and sulfosulfuron control the BLWs as well as the narrow also. Leaf area index (LAI) at 90 DAS was recorded higher with $100 \%$ RDF. Further, it was noted that $100 \%$ RDF treatment produced higher LAI over other at all the growth stages. Treatment $\mathrm{F}_{1}(100 \% \mathrm{RDF})$ recorded significantly higher LAI and remained at par with $\mathrm{F}_{2}(25 \% \mathrm{~N}-\mathrm{FYM}+75 \%$ $\mathrm{N}$ through chemical fertilizer) at 60 and 90 DAS. Maximum LAI (4.32 and 4.45) was noted with $\mathrm{F}_{1}(100 \% \mathrm{RDF})$ which showed an increase over other treatments (Table 5). It could be due to more growth and development in leaves due to adequate nitrogen supply. The nitrogen is very essential for chlorophyll synthesis in leaves, which helps in more photosynthesis and production of dry matter resulting increase in leaf area. Das et al., (1993) and Singh et al., (1996) also reported the similar results. Under weed management treatments, LAI was recorded 
higher with VESTA $400 \mathrm{~g} \mathrm{ha}^{-1}$. It might be because of fact that this formulation control the control the BLWs as well as narrow leaved weeds effectively without damaging the crop which gave better crop growth also.

On the basis of result of the experiment, it may be concluded that the suitable dose in nitrogen management practices for achieving higher productivity was found with $100 \%$ $\mathrm{RDF}$ and $25 \% \mathrm{~N} F Y M+75 \% \mathrm{~N}$ through chemical fertilizer $100 \%$ RDF gives maximum growth of crop whereas VESTA $400 \mathrm{~g} \mathrm{ha}^{-1}$ (Clodinafop propargyl 15\%+ metsulfuron methyl 1\%) (60+4g) controlled the narrow and BLWs very effectively and higher grain yield of wheat was recorded. application of VESTA (Clodinafop 15\% + metsulfuron methyl 1\%) controlled highest number of weeds which results in more crop growth under weed management treatments.

\section{References}

Anonymous (2015). Economic survey of India. Economics Division, Ministry of Finance, Govt. of India.

Bhagwati, P.C.; Faroda, A.S. and Malik, R.K. (1992). Response of wheat and associated weeds to application of nitrogen and Isoproturon. Indian $J$. Agron. 37(4):721-728.

Chandra Shekhar; Varshney, M.L.; Singh, J. and Singh, S.K. (1992). Response of wheat varieties to different levels of nitrogen. Narendra deva J. Agri. Res. 7(1): 169-171.

Das, D.K. ; Rao, T.V. and Das, D.K. (1993). Growth and spectral response of wheat as influenced by varying nitrogen levels and plant densities. Ann. Agri. Res. 14(4): 421-428.

Eid, R.A., Sedera, A. and Attia, M (2006). Influence of nitrogen fixing bacteria incorporation with organic and inorganic fertilizer on growth, flower yield and chemical composition of Celosis aregontia. World J. Agril. Sci., 2 (4):450-458.

Sharma, S.N. (2002). Nitrogen management in relation to wheat (Triticum aestivum) residue management in rice (Oryza sativa). Indian Journal of Agricultural Science 72:449-452.

Singh, G. (1991). Tillage and nitrogen requirement of wheat sown after paddy. Thesis, M.Sc. P.A.U. Ludhiana. Thesis Abstracts. 17:25-26.

Singh, V.; Katyal, S.K. and Panwar, K.S. (1996). Effect of application of biozyme with inorganic fertilizer of wheat. Indian J. Agron. 41(4):566-567.

Upadhyay, V.B. Nd Tiwari, J.P. (1996). Influence of nitrogen, seed rate and mulch on wheat (Triticum aestivum) varieties under late-sown conditions. Indian J. Agron. 41(4):562-565.

USDA (2017). World Agriculture Production. Pp-1-30.

\section{How to cite this article:}

Ankit Tiwari, O.P. Rai, Ghanshyam Singh, Manoj Kumar, Deepak Pandey and Harikesh. 2017. Studies on Influence of Nitrogen and Weed Management on Growth Characters of Late Sown Wheat (Triticum aestivum L.). Int.J.Curr.Microbiol.App.Sci. 6(11): 2087-2093. doi: https://doi.org/10.20546/ijcmas.2017.611.246 